\title{
Phylogenetic relationships of aquatic birnaviruses based on deduced amino acid sequences of genome segment A cDNA
}

\author{
S. Blake' , J .-Y. M a ${ }^{2}$, D. A. C aporale ${ }^{3}$, S. J airath ${ }^{1}$, B. L. N icholson ${ }^{1, *}$ \\ ${ }^{1}$ Department of Biochemistry, Microbiology and M olecular Biology, University of M aine, Orono, M aine 04469, USA \\ ${ }^{2}$ Millennium Pharmaceuticals, Inc. C ambridge, M assachusetts 02139, USA \\ ${ }^{3}$ Department of Biology, University of Wisconsin, Stevens Point, Wisconsin 54481, USA
}

\begin{abstract}
Aquatic birnaviruses, such as infectious pancreatic necrosis virus (IPNV), cause serious diseases in a variety of fish species used worldwide in aquaculture and have also been isolated from a variety of healthy fish and shellfish species. These viruses exhibit a high degree of antigenic heterogeneity and variation in biological properties such as pathogenicity, host range, and temperature of replication. To better understand genetic and biological diversity among these viruses, the nucleotide and deduced amino acid sequences were determined from cDNA of the large open reading frame (ORF) of genome segment A of the 9 type strains of Serogroup A and 4 other representative strains of Serotype A1, the predominant serotype in the United States. In addition, nucleotide and deduced amino acid sequences were determined for the VP2 coding region of a variety of isolates representing 5 of the 9 serotypes. VP2 is the major outer capsid protein of aquatic birnaviruses. RT-PCR was used to amplify a 2904 bp cDNA fragment including all but a few bp of the large ORF of genome segment A or a 1611 bp fragment representing the entire VP2 coding region. Nucleotide and deduced amino acid sequences were determined from the PCR products. Pairwise comparisons were made among our data and 2 other aquatic birnavirus sequences previously published. Several hypervariable regions were identified within the large ORF. The most divergent pair of viruses exhibited a similarity of $80.1 \%$ in the deduced amino acid sequence encoded by the large ORF. Genomic relationships revealed in a phylogenetic tree constructed from comparison of the deduced amino acid sequences of the large ORF demonstrated that these viruses were clustered into several genogroups. Phylogenetic comparison of the deduced amino acid sequences of the VP2 coding region of 28 aquatic birnavirus isolates, including the type strains of all 9 serotypes, demonstrated 6 genogroups, some of which were comprised of several genotypes. The most divergent pair of viruses exhibited a similarity of $81.2 \%$ in the deduced amino acid sequence from the VP2 coding region. In contrast to previous studies of much shorter genomic sequences within the C-terminus-pVP2/NS junction coding region, these genogroups based on the entire large ORF or the VP2 coding region generally correlated with geographical origin and serological classification. Isolates from the major Canadian serotypes were more closely related to the European isolates than to isolates from the United States.
\end{abstract}

KEY WORDS: Aquatic birnavirus · Infectious pancreatic necrosis virus · Genogroups - Phylogenetic relationships

\section{INTRODUCTION}

The aquatic birnaviruses are the largest and most diverse group of viruses within the family Birnaviridae;

*Corresponding author. E-mail: brucen@maine.edu they include a variety of viruses from numerous species of fish and marine invertebrates worldwide (Wolf 1988). These viruses exhibit a high degree of antigenic heterogeneity and variation in biological properties such as pathogenicity, host range, and temperature of replication. M any of these viruses have been proven or 
implicated as the etiologic agents of disease in a variety of fish species important in fish farming and aquaculture worldwide. Different strains of aquatic birnaviruses infect different species of fish and cause different diseases, such as infectious pancreatic necrosis (IPN) in salmonid species (Wolf 1988), nephroblastoma and branchionephritis in eel (Egusa 1970), and gill necrosis in clams (Lo et al. 1988).

All aquatic birnaviruses are similar in morphology and biochemical and biophysical properties (Dobos et al. 1979). The virion consists of an unenveloped, icosahedral capsid and a bisegmented, double stranded RNA genome (Cohen et al. 1973, M acDonald \& Yamamoto 1977, Dobos et al. 1979, Dobos \& Roberts 1983). The smaller genome segment $B$ (2784 bp) is monocistronic and encodes an internal polypeptide VP1 (94 kDa), the putative virion-associated RNA-dependent RNA polymerase. Genome segment A (approximately $3100 \mathrm{bp}$ ) contains 2 partially opverlapping open reading frames (ORF) (Duncan et al. 1987, Havarstein et al. 1990). The large ORF encodes a $106 \mathrm{kDa}$ polyprotein which is cleaved to produce 3 polypeptides: pVP2, the precursor of the major capsid protein VP2; VP3, a minor capsid protein; and NS, a non-structural protein. The pVP2 protein is further cleaved to VP2 during virus maturation. VP2 is the major outer capsid protein of the virus, whereas VP3 is thought to be an internal virion protein. The protease activity responsible for the cleavage has been associated with the non-structural virion protein NS (Duncan et al. 1987, Manning \& Leong 1990, Manning et al. 1990, Magyar \& Dobos 1994). The coding order for these polypeptides within the virion genome is $\mathrm{NH}_{2}-\mathrm{pVP2}-\mathrm{NS}-\mathrm{VP3}-\mathrm{COOH}$. The small ORF overlaps the amino terminal end of the polyprotein ORF in a different reading frame. This small ORF encodes a $17 \mathrm{kDa}$ arginine-rich minor polypeptide, designated VP5. VP5 has been detected in purified virus and infected cells (Magyar \& Dobos 1994) but its function is unknown. Complete nucleotide sequences of genome segment $A$ have been determined for only 5 strains: J asper-Dobos (J aD) (Duncan \& Dobos 1986), N1 (Havarstein et al. 1990), DRT (Chung, Lee, Lee, Ha, Lee \& Kim, 1994, GenBank acession no. D265527), Sp (M ason \& Leong, 1996, GenBank accession no. U48225) and West Buxton (WB) (Yao \& Vakharia 1998).

The vast majority of aquatic birnaviruses, regardless of host species or geographic origin, are related antigenically and form a major serogroup (Serogroup A), (Caswell-Reno et al. 1989, Nicholson 1993, Hill \& Way 1995). Relatively few antigenically unrelated aquatic birnaviruses represent a second, minor serogroup (Serogroup B). Considerable antigenic diversity exists among Serogroup A aquatic birnaviruses. Based on reciprocal neutralization tests with polyclonal antisera and enzyme immunoassays with monoclonal antibodies, Serogroup A contains 9 cross-reacting serotypes: A 1 (type strain West Buxton), A2 (type strain Sp), A3 (type strain Ab), A4 (type strain $\mathrm{He}$ ), A5 (type strain Te), A6 (type strain Canada 1), A 7 (type strain Canada 2), A8 (type strain Canada 3), and A9 (type strain J asper-ATCC VR 1325). Most aquatic birnavirus isolates from freshwater and marine fish in the United States belong to the $A 1$ serotype. Four serotypes (A6, $A 7, A 8$, and $A 9$ ) occur in Canada, and 4 serotypes (A2, $A 3, A 4$, and $A 5$ ) are found in Europe. Isolates representing Serotypes A1, A2, and A3 have been found in Asia and South America.

Relationships of aquatic birnaviruses have been studied at the genomic level in only a few investigations of a limited number of virus strains and/or relatively small genomic fragments. Comparing deduced amino acid sequences of a $310 \mathrm{bp}$ CDNA fragment located at the junction of the C-terminus of the PVP2 and the NS coding regions of 17 isolates, Heppell et al. (1993) suggested that only 3 major genogroups exist among the many Serogroup A viral strains. Little or no correlation was found among genogroups based on these VP2/NS cDNA sequences and the established serological groups. However, the region investigated was relatively small ( $310 \mathrm{bp}$ ) and located in the region of the junction of the VP2 and NS coding regions. M ore recently, Heppell et al. (1995) determined the nucleotide and deduced amino acid sequences of the VP2 coding region of 5 aquatic birnavirus strains.

In serological studies and in studies of nucleotide sequences and restriction endonuclease patterns of a $359 \mathrm{bp}$ fragment of genome segment A, Berthiaume et al. (1992) indicated that J asper strain viruses (J asperAmerican Type Culture Collection ATCC VR-1325 [J aATTC ] and J asper-Dobes [J aD]) maintained in 2 different laboratories, but originally obtained from the same source, were not identical. Thus, there has been some confusion regarding the true type strain of the J asper (A9) serotype of aquatic birnaviruses.

In order to better understand genetic relationships and diversity among these viruses, we compared the nucleotide and deduced amino acid sequences of a 2904 bp genomic fragment representing all but about 200 C-terminus nucleotides of the large ORF of genome segment $A$ of the 9 type strains of Serogroup A and 4 other representative strains of Serotype $A 1$, the predominant serotype in the United States. In addition, nucleotide and deduced amino acid sequences were determined for the VP2 coding region (1611 bp) of a variety of isolates (28 isolates) representing 5 of the 9 serotypes, including viruses from widely different geographical and host origins. The VP2 coding region was chosen for detailed investigation because VP2 is the major capsid protein and contains all neutralization epi- 
topes (Lipipun et al. 1992). These aquatic birnaviruses were clustered into 6 genogroups, several of which were comprised of several genotypes. In contrast to previous studies of shorter genomic sequences within the pVP2/NS coding region (Heppell et al. 1993), these genogroups, based on the entire large ORF and the entire VP2 coding region, generally correlated with geographical origin and serological classification. Interestingly, isolates from the major Canadian serotypes were more closely related to the European isolates than to isolates from the United States.

\section{MATERIAL AND METHODS}

C ell cultures. The Chinook salmon embryo cell line (CHSE-214) (Lannon 1984) was propagated as monolayer cultures using Eagle's minimum essential medium (MEM, Sigma Chemical Co., St. Louis, MO) supplemented with $0.2 \%$ sodium bicarbonate (Sigma) and either $10 \%$ fetal bovine serum (FBS, Hyclone Laboratories, Inc., Logan, UT) for routine cell cultivation or $2 \%$ FBS for virus propagation. The cells were incubated at $20^{\circ} \mathrm{C}$ in a $5 \% \mathrm{CO}_{2}$ incubator as previously described (Caswell-Reno et al. 1986).

Viruses. The aquatic birnavirus isolates used for sequence comparisons in this investigation are listed in Table 1. Included were 2 viruses, each reputed to be the J asper type strain but maintained in different laboratories. One strain studied by Duncan \& Dobos (1986) and determined to belong to Serotype $A 1$ is referred to as JaD; the other strain (ATCC, VR-1325) used in previous studies in our laboratory and determined to represent Serotype A9 is referred to as J a-ATCC. A variety of isolates representing the Buhl Serotype of Serogroup A (91-114,91-137, 64-93, 90-11, and CTT) were provided by Dr Paul Reno from Oregon State University. All other isolates have been maintained in our laboratory for many years.

Viral RNA extraction. The viral genomic RNA was extracted using the methods described by Blake et al. (1995). One hundred microliters of virus suspension was treated with $6 \mu \mathrm{l}$ Proteinase $\mathrm{K}$ ( $10 \mathrm{mg} \mathrm{ml}^{-1}$, Sigma) and lysis buffer (100 mM Tris- $\mathrm{HCl}, 1 \% \mathrm{SDS}, 150 \mathrm{mM} \mathrm{NaCl}$, $1.25 \mathrm{mM}$ EDTA, $\mathrm{pH} 7.4$ ) at $37^{\circ} \mathrm{C}$ for $3 \mathrm{~h}$. The mixture was extracted twice with an equal volume of phenolchloroform-isoamyl alcohol (25:24:1) solution. The aqueous phase was then precipitated at $-20^{\circ} \mathrm{C}$ overnight in the presence of 0.1 volume of $3 \mathrm{M}$ sodium acetate and 2.5 volumes of prechilled $100 \%$ ethanol. The nucleic acid was collected by centrifugation at $14000 \times \mathrm{g}$ for $30 \mathrm{~min}$ at $4^{\circ} \mathrm{C}$. The pellet was washed with $70 \%$ ethanol, dried at room temperature, and resuspended in $10 \mu \mathrm{l}$ of TE (10 mM Tris-HCl, 1 mM EDTA, pH 7.4) buffer. The extracted nucleic acid was stored in $-20^{\circ} \mathrm{C}$.
Table 1. Aquatic birnaviruses

\begin{tabular}{|c|c|c|c|}
\hline Virus & $\begin{array}{c}\text { Geographic } \\
\text { origin }\end{array}$ & $\begin{array}{l}\text { Host of } \\
\text { origin }\end{array}$ & Serotype \\
\hline West Buxton & M aine, USA & Trout & Al \\
\hline Dry Mills & Maine, USA & Trout & A1 \\
\hline VR299 & West Virginia, USA & Trout & A1 \\
\hline Buhl & Idaho, USA & Trout & Al \\
\hline Reno & Nevada, USA & Trout & A1 \\
\hline $64-93$ & Idaho, USA & Trout & $\mathrm{A} 1^{\mathrm{a}}$ \\
\hline $90-11$ & Idaho, USA & Trout & $\mathrm{A} 1^{\mathrm{a}}$ \\
\hline 91-114 & Idaho, USA & Trout & $\mathrm{A} 1^{\mathrm{a}}$ \\
\hline 91-137 & Idaho, USA & Trout & $\mathrm{A} 1^{\mathrm{a}}$ \\
\hline Sp & Denmark & Trout & $\mathrm{A} 2$ \\
\hline$N 1^{b}$ & Norway & Atlantic salmon & n A2 \\
\hline Fr 10 & France & Trout & A2 \\
\hline Fr 21 & France & Trout & A2 \\
\hline OV 2 & England & Oyster & $\mathrm{A} 2$ \\
\hline DPL & Thailand & Snakehead $\mathrm{N}$ & Not typed \\
\hline$A b$ & Denmark & Trout & A3 \\
\hline EEV & Japan & Eel & A3 \\
\hline E1S & Taiwan & Eel & A3 \\
\hline PV & Taiwan & Perch & A3 \\
\hline CV-HBI & Taiwan & Clam & A3 \\
\hline $\mathrm{He}$ & Germany & Pike & A4 \\
\hline Te & England & Tellina & A5 \\
\hline $\mathrm{C} 1$ & Canada & Trout & A6 \\
\hline ASV & Canada & Atlantic salmon & n A6 \\
\hline C2 & Canada & Trout & A7 \\
\hline C3 & Canada & Arctic char & A8 \\
\hline $\mathrm{JaD}^{\mathrm{c}}$ & Canada & Trout & A1 \\
\hline J aATCC & Canada & Trout & A9 \\
\hline \multicolumn{4}{|c|}{$\begin{array}{l}\text { aUnpublished data from Paul Reno, Oregon State University } \\
\text { bSequence from Havarstein et al. (1990) } \\
\text { 'Sequence from Duncan \& Dobos (1986) }\end{array}$} \\
\hline
\end{tabular}

Primers for PCR assays and CDNA nucleotide sequencing. Several oligonucleotide primers for PCR and CDNA sequencing were designed from the published CDNA sequence of genome segment $A$ of the $J a D$ (Duncan \& Dobos 1986) strain of aquatic birnavirus. The primer sequences and location within genome segment $A$ of aquatic birnaviruses are shown in Table 2. Different primer pairs were used for RT-PCR to amplify cDNA fragments that covered the large ORF of genome segment $A$.

Reverse transcription and polymerase chain reaction (RT-PCR). The RT-PCR procedure used in this study was a modification of the method previously described by Blake et al. (1995). Four microliters of viral RNA were mixed with $1.0 \mu \mathrm{l}$ containing $0.5 \mu \mathrm{g}$ of random hexamer primers and $2.2 \mu \mathrm{l}$ of sterile distilled water. After heating at $80^{\circ} \mathrm{C}$ for $5 \mathrm{~min}$ and cooling at room temperature, the sample was mixed with $12.8 \mu \mathrm{l}$ of RT master mix consisting of $4 \mu \mathrm{l}$ of $5 \times$ First Strand RT buffer (Gibco BRL), $0.3 \mu \mathrm{l}$ of $100 \mathrm{mM}$ DTT, $1.0 \mu \mathrm{l}$ (200 U) of Superscript II RNase $\mathrm{H}^{-}$Reverse Transcrip- 
Table 2. RT-PCR primer sets and amplified cDNA fragments used for sequencing

\begin{tabular}{|c|c|c|c|c|}
\hline & Primers (sequence) & Segment A position ${ }^{a}$ & PCR product length & Coding region \\
\hline $\begin{array}{l}\mathrm{Pb} 9 \\
\mathrm{~Pa} 8\end{array}$ & $\begin{array}{l}\text { (GAGAGCTCTTACGGAGGAG) } \\
\text { (GACATCAAGCTGTTGTAGG) }\end{array}$ & $39-547$ & 508 bp & Noncoding-VP2 \\
\hline $\begin{array}{l}\text { P8 } \\
\text { P10 }\end{array}$ & $\begin{array}{l}\text { (GGAAATACGACATCCAGAGCT) } \\
\text { (CACAGGATCATCTTGGCATAGT) }\end{array}$ & $421-1309$ & 988 bp & pVP2 \\
\hline $\begin{array}{l}\text { P15 } \\
\text { P12 }\end{array}$ & $\begin{array}{l}\text { (GAACGGAGCAAGGATGAGGTG) } \\
\text { (TGCACCACAGGAAAGATGACTC) }\end{array}$ & $683-1759$ & 1076 bp & VP2-NS \\
\hline $\begin{array}{l}\text { P14 } \\
\text { P1R }\end{array}$ & $\begin{array}{l}\text { (GTATCCAACTATGAGCTGAT) } \\
\text { (GTTCATGGGCGGCTATGGCTTT) }\end{array}$ & $1224-2160$ & 936 bp & pVP2-NS \\
\hline $\begin{array}{l}\text { P13 } \\
\text { P7 }\end{array}$ & $\begin{array}{l}\text { (GAGTCATCTTTCCTGTGGTGCA) } \\
\text { (TCTCATCAGCTGGCCCAGGTAC) }\end{array}$ & $1738-2312$ & 574 bp & NS \\
\hline $\begin{array}{l}\text { P1 } \\
\text { PY }\end{array}$ & $\begin{array}{l}\text { (AAAGCCATAGCCGCCCATGAAC) } \\
\text { (ATCAGTCAGGAAAGAGAGTA) }\end{array}$ & $2139-3062$ & 923 bp & VP3 \\
\hline $\begin{array}{l}\text { P17 } \\
\text { P1R }\end{array}$ & $\begin{array}{l}\text { (CCAGTTCATCGGAGATCTCAC) } \\
\text { (GTTCATGGGCGGCTATGGCTTT) }\end{array}$ & $1369-2160$ & $791 \mathrm{BP}$ & NS \\
\hline
\end{tabular}

tase (Gibco BRL), $0.5 \mu \mathrm{l}$ (20 U) of RNasin (Promega), and $4.0 \mu$ of $10 \mathrm{mM}$ dNTP $\mathrm{mix}$ (Promega). The reaction was performed at $42^{\circ} \mathrm{C}$ for $1 \mathrm{~h}$ and stopped by heating at $80^{\circ} \mathrm{C}$ for $5 \mathrm{~min}$. The PCR assay was performed with $10 \mu \mathrm{l}$ of CDNA, $5 \mu \mathrm{l}$ of 10× PCR buffer (Perkin Elmer Co.), $2.5 \mathrm{U}$ of AmpliTaq DNA polymerase (Perkin Elmer Co.), $0.1 \mu \mathrm{g}$ of each primer (sense and antisense) and 1.0 to $2.0 \mathrm{mM} \mathrm{Mg}^{+}$. The reaction mixture was adjusted to a final volume of $50 \mu \mathrm{l}$ with sterile distilled water. A mplification was performed in a Programmable Thermal Controller (PCT-100, MJ Research Inc.) using the program listed in Table 3. The RT-PCR products were separated by electrophoresis through a $2 \%$ SeaPlaque agarose gel (FMC Bioproducts) containing ethidium bromide $\left(0.5 \mu \mathrm{g} \mathrm{ml}^{-1}\right)$ in TAE buffer ( $40 \mathrm{mM}$ Tris, $20 \mathrm{mM}$ acetic acid, 2 mM EDTA). The ethidium-stained DNA bands were visualized by UV fluorescence.
Purification of RT-PCR amplification products. The amplified fragment of the expected length was cut out of the gel and transferred to a microcentrifuge tube, melted by heating at $65^{\circ} \mathrm{C}$ for $5 \mathrm{~min}$, and treated with $5 \mathrm{U}$ of Agarase (Sigma) were added to the tube. The samples were then incubated at $37^{\circ} \mathrm{C}$ overnight.

cDNA sequencing. The purified PCR products were cycle sequenced using Taq polymerase-mediated incorporation of dye-labeled dideoxy terminators. Ten microliters of PCR product $\left(0.1 \mu \mathrm{g} \mathrm{\mu l} \mathrm{l}^{-1}\right)$ were mixed with $9.5 \mu \mathrm{l}$ of Terminator Premix (PRISM Ready Reaction Sequencing Kit, Perkin Elmer, and $1 \mu \mathrm{l}$ of primer $(10 \mu \mathrm{M})$ in a $0.6 \mathrm{ml}$ microcentrifuge tube. The cycling reaction was performed in a Perkin-Elmer (M odel 480) thermal cycler using the following program: 25 cycles of $96^{\circ} \mathrm{C}$ for $30 \mathrm{~s}$, $50^{\circ} \mathrm{C}$ for $15 \mathrm{~s}$, and $60^{\circ} \mathrm{C}$ for $4 \mathrm{~min}$. The reaction mixture was then loaded on the top layer of a prewashed Spin-

Table 3. PCR amplification protocol for each pair of primers

\begin{tabular}{|c|c|c|c|c|c|c|}
\hline \multirow{2}{*}{$\begin{array}{l}\text { Primer } \\
\text { pair }\end{array}$} & \multirow{2}{*}{$\begin{array}{l}\mathrm{Mg}^{++} \\
(\mathrm{mM})\end{array}$} & & 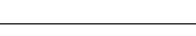 & \multicolumn{3}{|l|}{ Amplification - } \\
\hline & & $\begin{array}{c}\text { Denaturation } \\
\left({ }^{\circ} \mathrm{C} / \mathrm{min}\right)\end{array}$ & $\begin{array}{c}\text { Denaturation } \\
\left({ }^{\circ} \mathrm{C} / \mathrm{s}\right)\end{array}$ & $\begin{array}{c}\text { Annealing } \\
\left({ }^{\circ} \mathrm{C} / \mathrm{s}\right)\end{array}$ & $\begin{array}{l}\text { Extension } \\
\left({ }^{\circ} \mathrm{C} / \mathrm{min}\right)\end{array}$ & $\begin{array}{c}\text { Final } \\
\left({ }^{\circ} \mathrm{C} / \mathrm{min}\right)\end{array}$ \\
\hline $\mathrm{Pb9/Pa8}$ & 1.0 & & & & & \\
\hline P15/P12 & 1.0 & $93 / 2$ & $92.5 / 45$ & $58 / 45$ & $72 / 1.75$ & $72 / 7$ \\
\hline P14/P1R & 1.0 & & & & & \\
\hline $\begin{array}{l}\text { P8/P10 } \\
\text { P17/P1R }\end{array}$ & $\begin{array}{l}1.5 \\
1.5\end{array}$ & $93 / 2$ & $92.5 / 45$ & $59 / 45$ & $72 / 1.75$ & $72 / 7$ \\
\hline P13/P7 & 1.5 & $93 / 2$ & $92.5 / 45$ & $58 / 45$ & $72 / 1.75$ & $72 / 7$ \\
\hline P1/PY & 2.0 & $100 / 5$ & $95 / 45$ & $60 / 45$ & $72 / 1.75$ & $72 / 7$ \\
\hline
\end{tabular}


Column (Sepharose 100). The column was placed in a microcentrifuge tube and centrifuged at $750 \times \mathrm{g}$ for $2 \mathrm{~min}$ to remove unincorporated nucleotides. The sample was dried in a vacuum centrifuge and resuspended with $4 \mu \mathrm{l}$ of loading buffer $(83.3 \%$ [v/v] deionized formamide, $16.7 \%[\mathrm{v} / \mathrm{v}] 50 \mathrm{mM}$ EDTA, pH 8.0). The sample was denatured at $90^{\circ} \mathrm{C}$ for $2 \mathrm{~min}$, then immediately transferred into an ice bath and loaded onto a $7 \%$ polyacrylamide gel in an ABI Model 373A DNA sequencer at the University of $M$ aine DNA Sequencing Facility.

Sequence analyses. Sequences were edited using the Sequence Navigator (A pplied Biosystems, Inc.) Program. Deduced amino acid sequences were derived with the DNASTAR (Lasergene, Inc.) EditSeq computer program. Multiple sequence alignments were performed using the DNASTAR (Lasergene, Inc.) M egAlign program, with suggested parameters of Unweighted Gap penalty of 10 , and Gap length penalty of 10 . Phylogenetic trees were constructed with the Clustal algorithm of the MegAlign program and maximum parsimony analysis using Branch and Bound algorithm of PAUP version 3.1.

$\mathrm{N}$ ucleotide accession numbers. The nucleotide and deduced amino acid sequence data reported in this paper have been deposited in GenBank with the following accession numbers: West Buxton, AF342727; Dry Mills, AF343571; VR299, AF343572; Buhl, AF343573; Reno, AY 026345; 64-93, AY 026346; 90-11, AY 026347; 91-114, AY 026348; 91-137, AF343570; Sp, AF342728; Fr10, AY 026482; Fr21, AY 026483; OV2, AY 026484; DPL, AY 026485; Ab, AF342729; EEV, AY 026486; E1S, AY 026487; PV, AY 026488; CV-HB1, AY 026489; He, AF342730; Te, AF342730; C1, AF342731; A SV, AY 026490; C2, AF342733; C3, AF342734; Ja-ATCC, AF342735.

\section{RESULTS}

In this study, we investigated the genomic relationships of 28 viruses, including the type strains of all 9 serotypes of Serogroup A. The nucleotide and deduced amino acid sequences of CDNA of the large ORF (2904 bp) of genome segment A were determined for the type strains of the 9 serotypes. The J asper-ATCC strain (Serotype A9) that was used in previous serological investigations in our laboratory was analyzed at the nucleic acid and deduced amino acid levels in this study. Large ORF CDNA sequences were obtained for 5 individual strains (Dry Mills [DM ], VR299, Buhl, West Buxton [WB] and 91-137) of Serotype A1 (WB), the predominate serotype in the United States. In addition, nucleotide and deduced amino acid sequences were determined for the VP2 coding region (1116 bp) of a variety of isolates representing 5 of the 9 serotypes. The 28 viruses used in this investigation represented widely different geographical and host origins. The deduced amino acid sequences, numbered from the beginning of the large ORF, of the virus strains sequenced in this study are shown in Fig. 1 along with those of the J $\mathrm{aD}$ and $\mathrm{N} 1$ strain sequences reported previously by other investigators (Duncan \& Dobos 1986, Havarstein et al. 1990).

With all the viruses studied, the domain corresponding to amino acid residues 243-335 (Fig. 1) was highly variable, which also was previously observed by Heppell et al. (1995). In addition, in this study, other, smaller variable regions were identified with specific variations corresponding to a specific serotype or serotypes. Moreover, many highly conserved signature amino acid residues were identified within the VP2 protein that distinguish certain serotypes (Tables $4 \& 5$ ). These highly conserved signature amino acids clearly distinguished isolates from the United States and the $J$ asper strains from the other 3 Canadian serotypes and the European and Asian isolates (Table 4).

Comparisons of the nucleotide and deduced amino acid sequences of the large ORF of the 9 type strains (WB, Sp, Ab, Te, C1,C2, C3, He and J aATCC) as well as 4 other isolates of Serotype $A 1$ and the previously reported sequences of the $\mathrm{N} 1$ and $\mathrm{J} \mathrm{aD}$ strains are shown in Tables $6 \&$ 7. All isolates from the United States and the $2 \mathrm{~J}$ asper strains exhibited $89-99.6 \%$ identity in nucleotide sequences compared to $69.0-77.4 \%$ identity to the viruses from Canada, Europe and Asia. The deduced amino acid sequences of all isolates from the United States and the 2 J asper strains were $\geq 95 \%$ similar to each other but only 80.1 to $84 \%$ similar to the

Table 4. Signature amino acid residues distinguishing United States and J asper strains from other Canadian, European and Asian strains

\begin{tabular}{|c|c|c|}
\hline $\begin{array}{l}\text { Amino acid } \\
\text { position }\end{array}$ & $\begin{array}{l}\text { US/J asper } \\
\text { strains }\end{array}$ & $\begin{array}{l}\text { European, Asian } \\
\text { and Canadian strains }\end{array}$ \\
\hline 12 & Arg & Lys \\
\hline 19 & Asn & Thr \\
\hline 72 & Leu & Ala or Val \\
\hline 243 & Thr & Asn or Ser \\
\hline 261 & GIn & Asp or Glu \\
\hline 311 & Ala & Ser or Thr \\
\hline 313 & GIn & Lys \\
\hline 426 & Ala & Val \\
\hline 434 & Thr & Ser \\
\hline 448 & Asp & Ile \\
\hline 486 & Ser & Ala \\
\hline 543 & Phe & Val \\
\hline 561 & Val & Ala \\
\hline 562 & Val & Ile \\
\hline 563 & Val & Ile \\
\hline 537 & Ala & Gly \\
\hline 648 & Ile & Val \\
\hline 665 & Val & Ile \\
\hline 688 & Cys & Asn \\
\hline 695 & Met & Glu \\
\hline 703 & Ser & Ala \\
\hline 717 & GIn & Lys \\
\hline
\end{tabular}



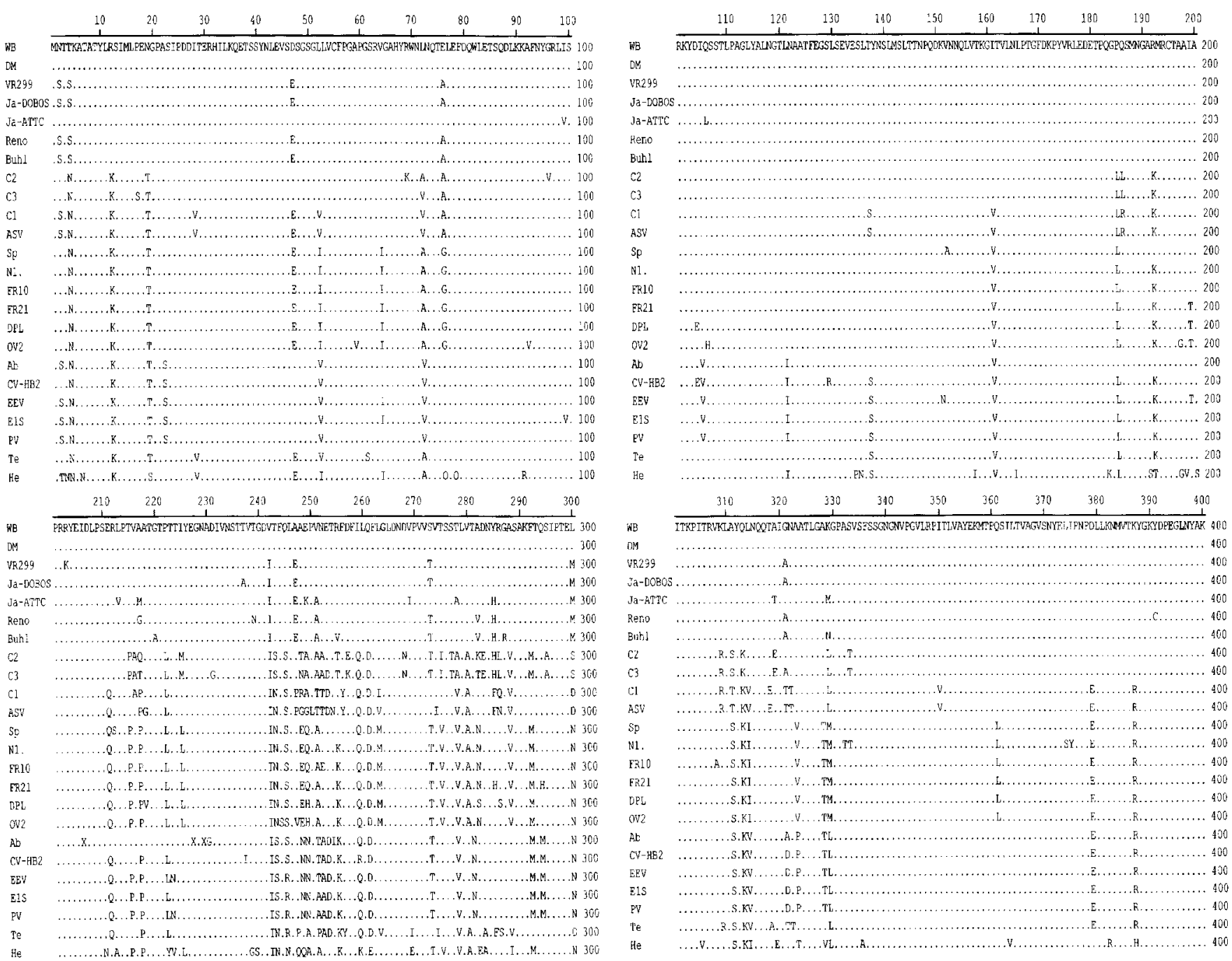

Fig. 1. (A bove and facing page). Multiple alignment of deduced amino acid sequences encoded by large LORF of genome segment $A$ of various aquatic birnaviruses. (.) indicates an amino acid residue identical to that of strain WB

viruses from Canada, Europe and Asia. The 2 most divergent pairs of viruses were Buhl and $\mathrm{He}$, with a similarity in amino acid sequences of $80.1 \%$.

Trees were constructed using maximum parsimony analysis to describe the phylogenetic history of these viruses based on the deduced amino acid similarities of the polyprotein encoded by the large ORF. The most parsimonious tree was found using the Branch and Bound algorithm of PAUP, Version 3.1, with 1000 bootstrap replicates performed to evaluate the reliability of the reconstructions. Distance trees were also constructed using a heuristic search computed by PAUP, with 1000 bootstrap replicates, and the Clustal distance method computed by DNAStar Lasergene. The tree topologies were identical using these 3 methods. Branch lengths were drawn proportional to the number of deduced amino acid differences using the Clustal distance method and bootstrap values from the parsimony analysis were included in the branches (Fig. 2). The cladogram of these phylogenetic relationships (Fig. 2) suggests that these viruses may represent 4 or 5 distinct genomic clusters. Clearly, the isolates from the United States and the J asper strains appear to represent one distinct group.

Comparison of the genomic relationships of the different viral isolates based on the nucleotide sequences of the VP2 coding region (Table 8) demonstrated identities of $87.9-99.7 \%$ among the isolates from the United States and the J asper strains, compared to $76.5-80.2 \%$ with the Canadian, European and Asian strains. The deduced amino acid sequences (Table 9) of all isolates from the United States and the $2 \mathrm{~J}$ asper strains were more than $94 \%$ similar to each other, but were more divergent from the Canadian, European and Asian viruses. Other pairs or groups of viruses also exhibited high similarities to each other in amino acid sequences 

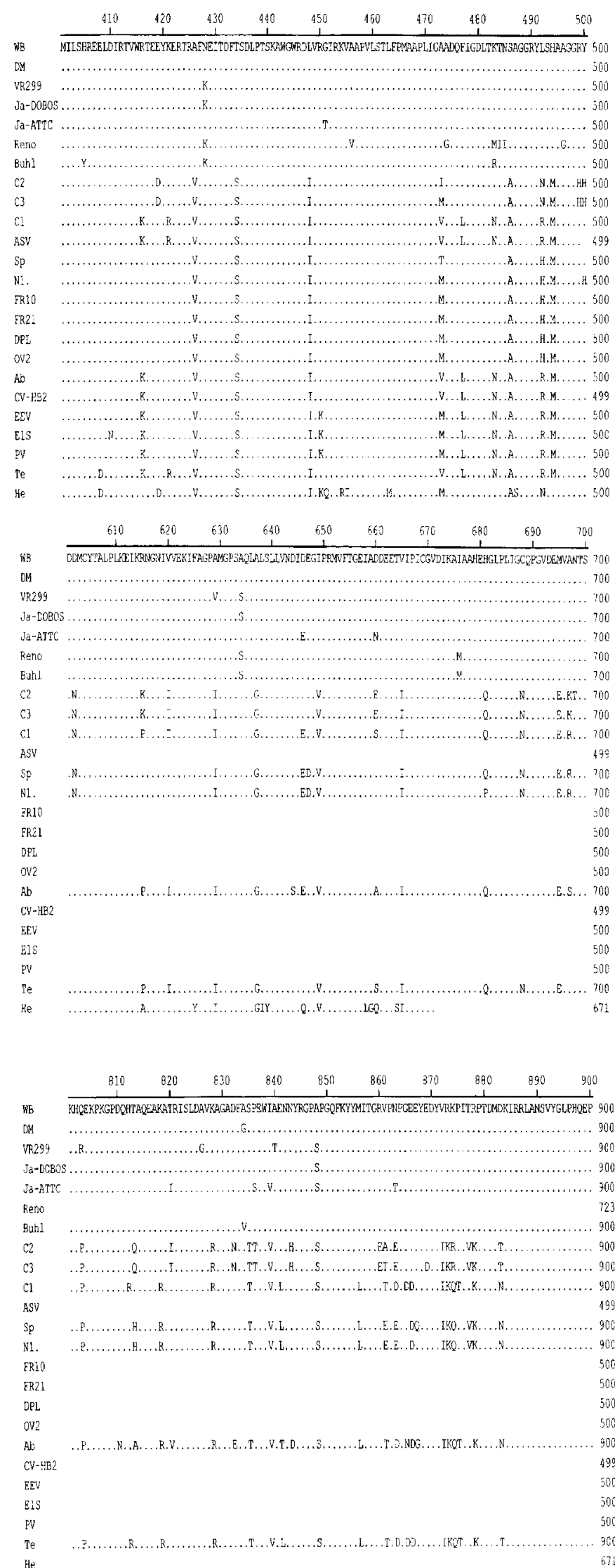
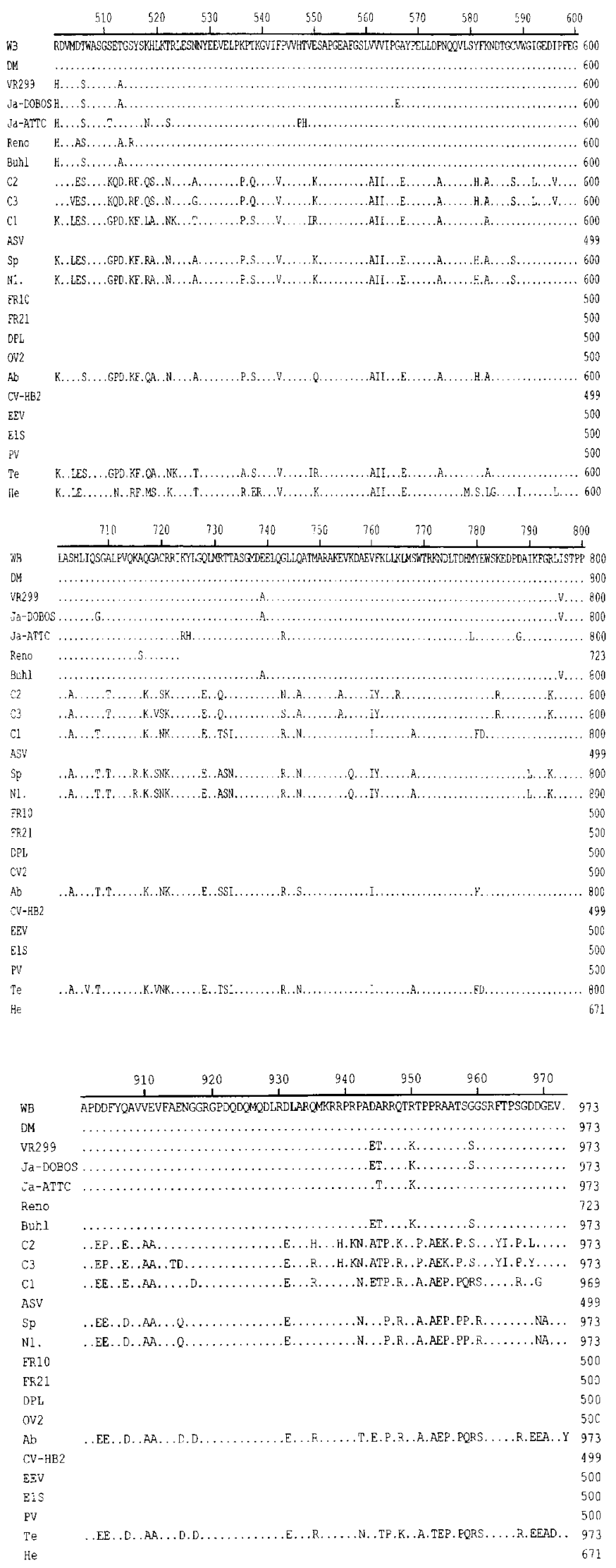
Table 5. Signature amino acid residues distinguishing other groups of aquatic birnavirus isolates

\begin{tabular}{|lcc|}
\hline Viruses & $\begin{array}{c}\text { Amino } \\
\text { acid position }\end{array}$ & $\begin{array}{c}\text { Unique signature } \\
\text { amino acid }\end{array}$ \\
\hline Sp, N1, Fr10, Fr21, PDL, OV2 & 76 & Gly \\
& 263 & Met \\
& 314 & Ile \\
& 232 & Val \\
Ab, CV-HB1, EEV, E1S, PV & 361 & Leu \\
& 22 & Ser \\
& 105 & Val \\
C2, C3 & 281 & Asn \\
& 294 & Met \\
& 225 & Met \\
& 255 & Thr \\
& 267 & Asn \\
& 275 & Ile \\
& 276 & Thr \\
& 283 & Glu \\
& 286 & Leu \\
& 295 & Ala \\
& 300 & Ser \\
C1, Te & 319 & Glu \\
& 246 & Pro \\
& 256 & Tyr \\
& 285 & Phe \\
& 288 & Val \\
& 321 & Th \\
\hline & & \\
& &
\end{tabular}

but were less closely related to other isolates. The highest degree of divergence (18.8\%) was exhibited between the $\mathrm{He}(\mathrm{A} 1)$ type strain and the Reno and 90-11 strains representing the WB (A1) serotype.

A classification of these aquatic birnaviruses was determined on the basis of deduced amino acid similarities of VP2 using M egalign and PAUP as descibed previously (Fig. 3). The 28 aquatic birnavirus isolates were clustered into 6 genogroups that generally correlated with geographic origin of the virus and previous serological classifications. Genogroup 1 consisted of all isolates from the United States (Serotype A 1) and the 2 J asper strains from C anada. Genogroup 2 contained all of the isolates belonging to Serotype A3, including viruses from both Europe and A sia. Two Canadian isolates representing Serotype A6 (C1 and ASV) and the type strain (Te) of the European serotype A5 formed Genogroup 3. The type strains of the 2 Canadian Serotypes A7 (C2) and A 8 (C3) comprised Genogroup 4. All members of Serotype A2, including 5 European isolates and 1 Asian isolate, formed Genogroup 5. The He strain, the only known representative of Serotype A4, represented Genogroup 6. Interestingly, viruses representing the 3 major serotypes found in Canada (A6, $A 7$, and $A 8$ ) were more closely related to the European and Asian isolates (Serotypes A2, A3, A4, and A5) than

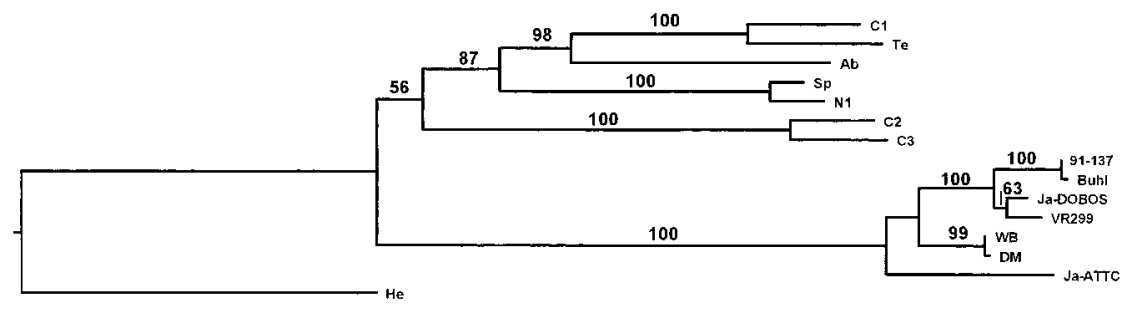

Fig. 2. Cladogram representing phylogenetic relationships of aquatic birnaviruses based on deduced amino acid sequences of VP2. The length of each pair of branches represents the distance between sequence pairs, and the numbers indicate the bootstrap values

Table 6. Pairwise distances of aquatic birnaviruses based on nucleotide sequences of large ORF of genome segment A

\begin{tabular}{|c|c|c|c|c|c|c|c|c|c|c|c|c|c|c|c|c|}
\hline & & & & & & & Per & ent ide & tity & & & & & & & \\
\hline & & WB & DM & $\mathrm{J} a \mathrm{aD}$ & VR299 & 91137 & Buhl & $\mathrm{J} a \mathrm{~A}$ & Sp & N1 & $A b$ & $\mathrm{Cl}$ & C2 & C3 & $\mathrm{Te}$ & $\mathrm{He}$ \\
\hline & WB & & 99.6 & 91.1 & 91.0 & 90.7 & 89.0 & 90.6 & 77.1 & 77.0 & 77.4 & 76.8 & 76.1 & 75.7 & 75.8 & 70.1 \\
\hline & DM & 0.4 & & 91.1 & 91.0 & 90.8 & 88.9 & 90.6 & 77.0 & 76.8 & 77.2 & 76.8 & 76.1 & 75.8 & 75.7 & 70.3 \\
\hline & $\mathrm{JaD}$ & 8.5 & 8.6 & & 99.6 & 98.1 & 96.4 & 91.4 & 76.9 & 76.7 & 77.2 & 76.2 & 76.2 & 75.8 & 75.8 & 70.8 \\
\hline & VR299 & 8.6 & 8.6 & 0.4 & & 98.0 & 96.2 & 91.2 & 76.9 & 76.7 & 77.1 & 76.3 & 76.2 & 75.7 & 75.8 & 70.7 \\
\hline$\breve{\Xi}$ & 91137 & 8.9 & 8.9 & 1.9 & 2.0 & & 97.5 & 90.7 & 77.0 & 77.0 & 77.0 & 76.3 & 76.4 & 76.0 & 76.0 & 71.0 \\
\hline $\bar{\sigma}$ & Buhl & 9.2 & 9.4 & 2.2 & 2.3 & 1.1 & & 89.1 & 75.3 & 75.3 & 75.4 & 74.6 & 74.7 & 74.3 & 74.3 & 69.0 \\
\hline$\frac{5}{2}$ & J aATCC & 8.8 & 8.8 & 8.4 & 8.5 & 8.9 & 9.1 & & 76.8 & 76.7 & 76.7 & 76.4 & 76.4 & 76.3 & 75.7 & 70.5 \\
\hline$\geq$ & $\mathrm{Sp}$ & 20.8 & 20.7 & 20.8 & 20.8 & 20.7 & 21.0 & 20.8 & & 98.2 & 85.9 & 85.9 & 83.4 & 83.1 & 86.3 & 75.1 \\
\hline$\stackrel{\Perp}{c}$ & N1 & 20.9 & 20.9 & 21.0 & 21.0 & 20.7 & 21.0 & 20.9 & 1.7 & & 85.8 & 86.2 & 83.6 & 83.5 & 86.8 & 75.1 \\
\hline $\bar{\Xi}$ & $A b$ & 19.9 & 20.0 & 20.3 & 20.4 & 20.4 & 20.6 & 20.5 & 13.1 & 13.2 & & 87.0 & 81.5 & 81.7 & 86.3 & 73.2 \\
\hline$\frac{1}{2}$ & $\mathrm{C} 1$ & 21.0 & 21.0 & 21.2 & 21.1 & 21.1 & 21.5 & 21.2 & 13.3 & 13.0 & 12.3 & & 82.4 & 83.0 & 91.0 & 73.0 \\
\hline & C2 & 21.7 & 21.7 & 21.7 & 21.7 & 21.6 & 21.8 & 21.3 & 15.2 & 15.1 & 17.0 & 16.4 & & 97.0 & 81.4 & 73.3 \\
\hline & C3 & 22.0 & 21.8 & 22.0 & 22.0 & 21.8 & 22.1 & 21.4 & 15.4 & 15.0 & 16.9 & 15.9 & 3.0 & & 81.6 & 72.9 \\
\hline & $\mathrm{Te}$ & 21.5 & 21.5 & 21.4 & 21.4 & 21.4 & 21.7 & 21.5 & 12.8 & 12.5 & 12.8 & 8.7 & 17.1 & 16.8 & & 73.8 \\
\hline & $\mathrm{He}$ & 25.9 & 25.7 & 25.5 & 25.5 & 25.3 & 25.8 & 25.6 & 22.6 & 22.5 & 24.1 & 24.2 & 23.9 & 24.4 & 23.6 & \\
\hline
\end{tabular}




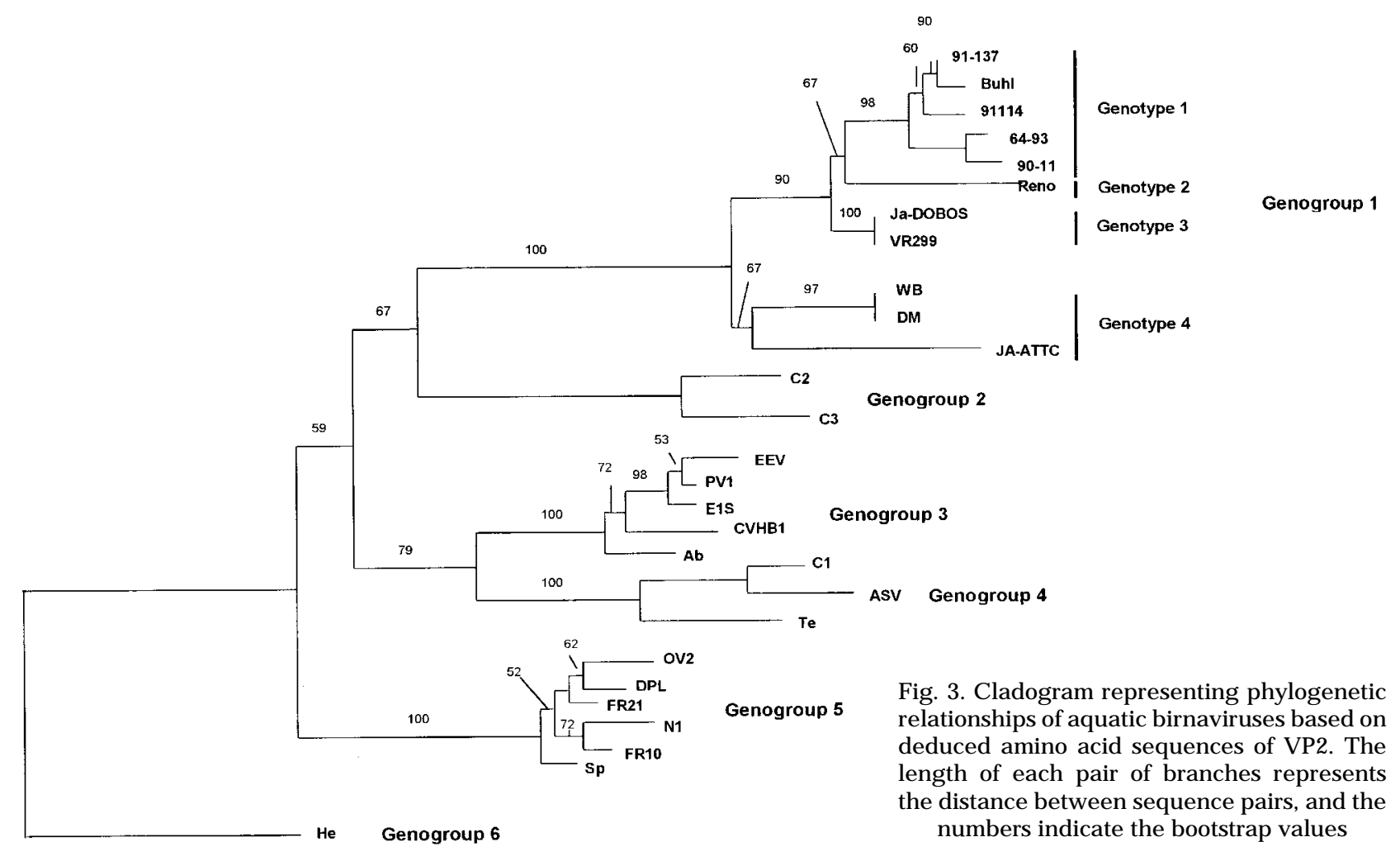

to isolates representing the prevalent serotype (A1) in the United States.

Some genogroups comprised of a number of viruses appeared to contain 2 or more genotypes. This is particularly evident in Genogroup 1, in which 4 genotypes can be identified that corresponded to previously identified specific serological strains. Previous investigations using monoclonal antibodies have shown that at least 4 distinct strains of aquatic birnaviruses can be identified within Serotype A 1: WB strain, VR299 strain, Buhl strain, and Reno strain (Caswell-Reno et al. 1986, 1989, P. Reno, Oregon State University, pers. comm.). Genotype 1 contained 5 viruses (Buhl, 91-114, 91-137, 64-93, and 90-11) that were previously shown using monoclonal antibodies to belong to a single serological strain (Buhl strain) within the A1 serotype. Three, or possibly 4, other genotypes were also identified within Genogroup 1. Genotype 2 included strain VR299 and the

Table 7. Pairwise distances of aquatic birnaviruses based on deduced amino acid sequences of large ORF of genome segment $\mathrm{A}$

\begin{tabular}{|c|c|c|c|c|c|c|c|c|c|c|c|c|c|c|c|c|}
\hline & \multicolumn{15}{|c|}{ Percent similarity } \\
\hline & & WB & $\mathrm{DM}$ & $\mathrm{J} a \mathrm{D}$ & VR299 & 91137 & Buhl & J aA & $\mathrm{Sp}$ & N1 & $A b$ & $\mathrm{C} 1$ & $\mathrm{C} 2$ & $\mathrm{C} 3$ & $\mathrm{Te}$ & $\mathrm{He}$ \\
\hline & WB & & 99.9 & 97.5 & 97.3 & 96.9 & 96.8 & 96.3 & 85.3 & 84.9 & 84.9 & 84.2 & 84.3 & 83.8 & 84.2 & 81.1 \\
\hline & DM & 0.1 & & 97.4 & 97.2 & 96.9 & 96.8 & 96.2 & 85.2 & 84.8 & 84.8 & 84.1 & 84.2 & 83.7 & 84.1 & 81.0 \\
\hline & $\mathrm{JaD}$ & 2.5 & 2.6 & & 99.2 & 98.6 & 98.5 & 95.5 & 84.5 & 84.1 & 84.5 & 84.2 & 83.7 & 83.4 & 83.6 & 80.6 \\
\hline 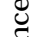 & VR299 & 2.7 & 2.8 & 0.8 & & 98.3 & 98.2 & 95.2 & 84.4 & 84.0 & 84.4 & 84.1 & 83.7 & 83.4 & 83.5 & 80.4 \\
\hline $\bar{\Phi}$ & 91137 & 3.1 & 3.1 & 1.4 & 1.7 & & 99.9 & 95.1 & 84.0 & 83.7 & 84.0 & 83.7 & 83.6 & 83.3 & 83.2 & 80.2 \\
\hline$\frac{0}{\omega}$ & Buhl & 3.2 & 3.2 & 1.5 & 1.8 & 0.1 & & 95.0 & 83.9 & 83.6 & 83.9 & 83.6 & 83.5 & 83.2 & 83.1 & 80.1 \\
\hline$\geq$ & J aATCC & 3.7 & 3.8 & 4.5 & 4.8 & 4.9 & 5.0 & & 84.2 & 83.8 & 83.7 & 83.4 & 83.7 & 83.2 & 83.4 & 80.2 \\
\hline \pm & Sp & 14.7 & 14.8 & 15.5 & 15.6 & 16.0 & 16.1 & 15.8 & & 98.8 & 90.5 & 91.1 & 88.5 & 88.2 & 90.3 & 84.6 \\
\hline Ф్ర & N1 & 15.1 & 15.2 & 15.9 & 16.0 & 16.3 & 16.4 & 16.2 & 1.2 & & 90.1 & 90.8 & 88.7 & 88.5 & 90.2 & 84.5 \\
\hline$\frac{5}{\mathscr{\omega}}$ & $A b$ & 14.8 & 14.9 & 15.2 & 15.3 & 15.8 & 15.9 & 16.1 & 9.2 & 9.6 & & 92.0 & 86.5 & 87.0 & 91.5 & 82.1 \\
\hline$\alpha$ & $\mathrm{C} 1$ & 15.8 & 15.9 & 15.8 & 15.9 & 16.3 & 16.4 & 16.6 & 8.9 & 9.2 & 7.7 & & 87.0 & 87.3 & 96.5 & 82.3 \\
\hline & $\mathrm{C} 2$ & 15.7 & 15.8 & 16.3 & 16.3 & 16.4 & 16.5 & 16.3 & 11.5 & 11.3 & 13.3 & 13.0 & & 97.4 & 86.5 & 82.6 \\
\hline & C3 & 16.2 & 16.3 & 16.6 & 16.6 & 16.7 & 16.8 & 16.8 & 11.8 & 11.5 & 12.7 & 12.7 & 2.6 & & 86.8 & 82.3 \\
\hline & $\mathrm{Te}$ & 15.8 & 15.9 & 16.4 & 16.5 & 16.8 & 16.9 & 16.6 & 9.7 & 9.8 & 8.2 & 3.5 & 13.5 & 13.2 & & 82.9 \\
\hline & $\mathrm{He}$ & 18.8 & 18.9 & 19.3 & 19.5 & 19.8 & 19.9 & 19.8 & 15.3 & 15.4 & 17.5 & 17.6 & 17.3 & 17.6 & 17.1 & \\
\hline
\end{tabular}




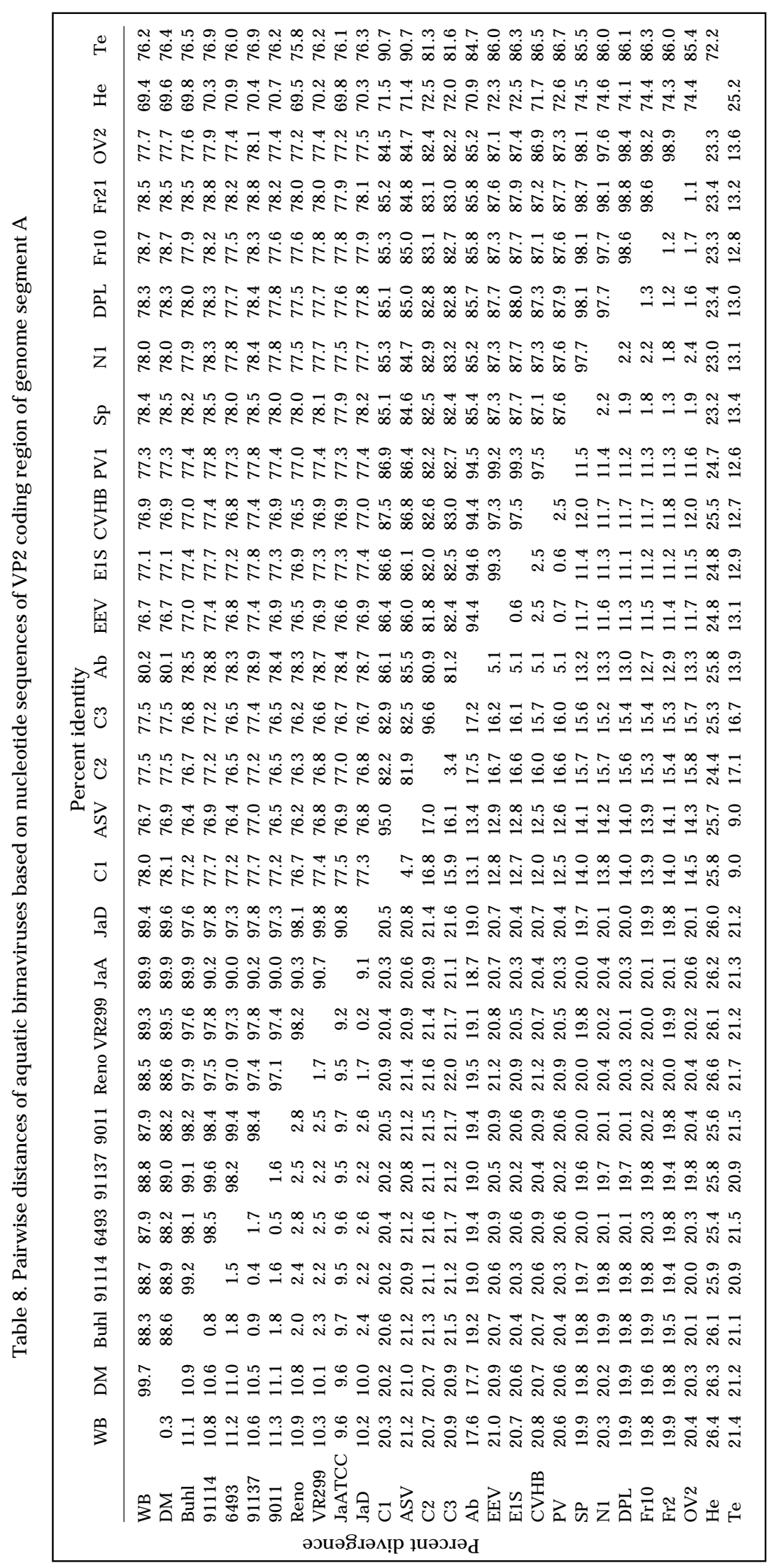

$\mathrm{JaD}$ strain. The Reno strain constituted Genotype 3. Genotype 4 was formed by WB and DM , both of which represent the same strain identified by monoclonal antibody reaction patterns. The J aATCC strain, which currently constitutes a separate serotype may or may not represent a fifth genotype within Genogroup 1.

\section{DISCUSSION}

Complete sequences of genome segment $A$, which encodes the virion structural proteins and the protease responsible for cleavage of the primary polyprotein gene product, are available for only 4 aquatic birnavirus strains: Sp, N1 (Haverstein et al. 1990), JaD (Duncan \& Dobos 1986), and DRT (Chung, Lee, Lee, Ha, Lee \& Kim, 1994, GenBank accession no. D26527). Previous investigations of relationships of aquatic birnaviruses based on genomic nucleotide and deduced amino acid sequences focused on relatively short genomic fragments and/or a limited number of viral isolates (Heppell et al. 1993, 1995). In this study, we investigated the genomic relationships of 28 aquatic birnaviruses that represent widely different geographical and host origins, including the type strains of all 9 serotypes of Serogroup A.

Previously, Heppell et al. (1995) reported a central variable domain encompassing 2 hypervariable segments within the VP2 coding region based on a study of 7 virus strains. This variable domain corresponding to amino acid residues 243-335 was confirmed in this study of 28 viruses (Fig. 1).

High levels of identity (89 to $99.6 \%$ ) were found among all isolates from the United States and the 2 Jasper strains but these viruses showed much lower identity levels (73.3 to $77.4 \%$ ) when compared to viruses from Canada, Europe and Asia (Tables $6 \& 7$ ). In terms of deduced amino acid sequences, all isolates from the United States and 


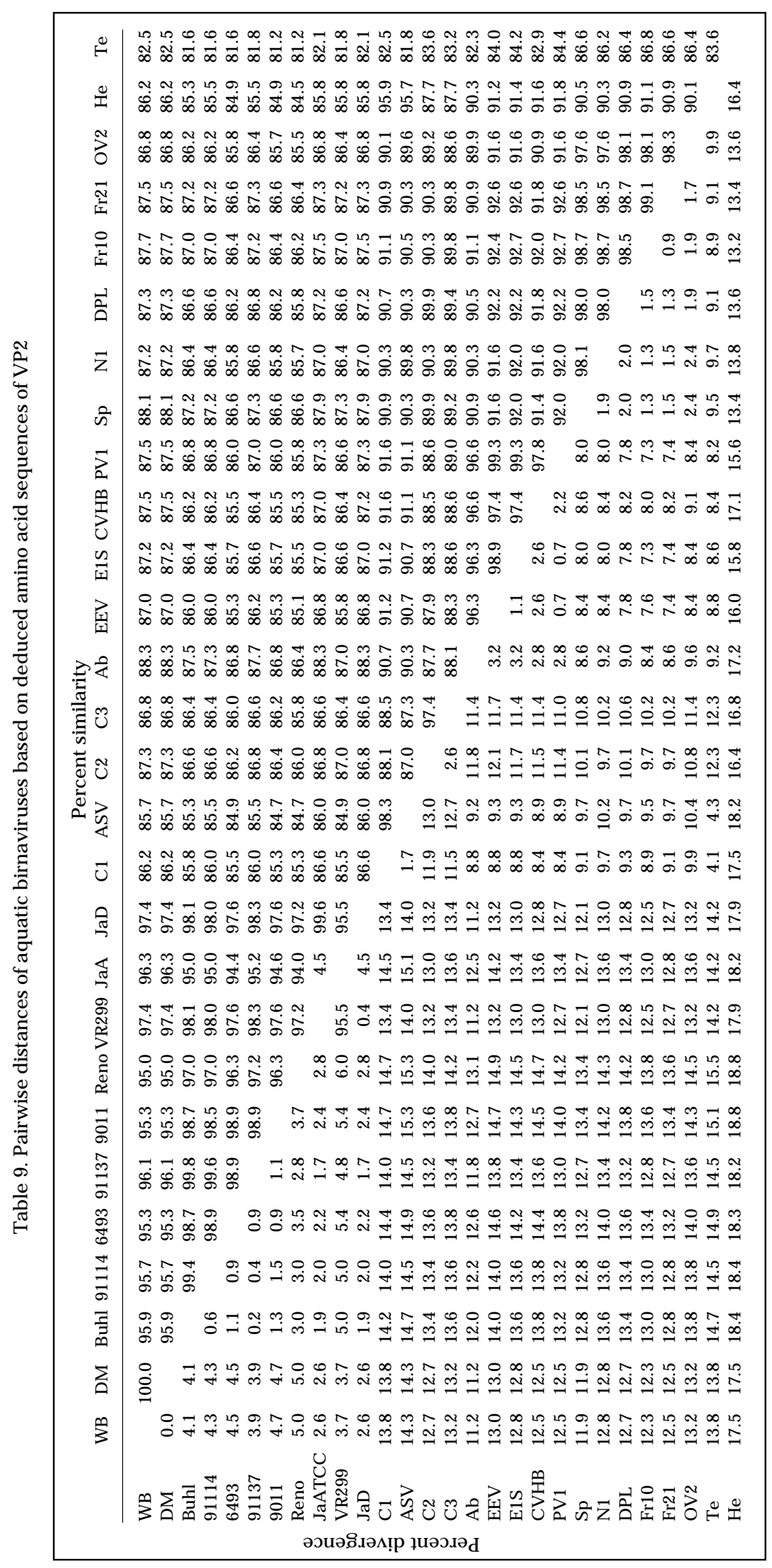

the 2 J asper strains also were very closely related ( $\geq 95 \%$ similarity) but were less closely related (83 to $84 \%$ similarity) to the viruses from Canada, Europe and Asia. The 2 most divergent pairs of viruses were Buhl and $\mathrm{He}$ with a similarity in amino acid sequences of $80.1 \%$. A phylogenetic tree based on the deduced amino acid similarities of the polyprotein encoded by the large ORF (Fig. 2) suggested that these viruses may represent 4 or 5 distinct genomic clusters. Clearly, the isolates from the United States and the J asper strains appeared to represent a distinct group.

More detailed information about the genomic relationships of these aquatic birnaviruses was obtained by comparison of the nucleotide and deduced amino acid sequences of the VP2 coding region (1611 bp) of a variety of isolates representing all 9 serotypes of Serogroup A and widely different geographical and host origins. The VP2 coding region was chosen for detailed investigation because VP2 is the major outer capsid protein and contains all neutralization epitopes (Lipipun et al. 1992) and cell attachment sites that determine host/cell range. Comparison of the nucleotide sequences of the VP2 coding region of these 28 viruses (Table 8) demonstrated identities of 87.9-99.7\% among the isolates from the United States and the Jasper strains, compared to $76.5-80.2 \%$ with the Canadian, European and Asian strains. The deduced amino acid sequences (Table 9) of all isolates from the United States and the 2 Jasper strains were more than $94 \%$ similar to each other but exhibited less similarity with the Canadian, European and Asian viruses. Other pairs or groups of viruses also exhibited high similarities to each other in amino acid sequences but less similarity to other isolates. The highest degree of divergence (18.8\%) was exhibited between the $\mathrm{He}$ (A4) type strain and the Reno and $90-11$ strains representing the WB (A1) serotype. 
Distinguishing the US isolates and the J asper strains from the other Canadian, European and Asian strains were a number of highly conserved signature amino acid residues identified within the VP2 protein. A number of signature amino acids were shown to be universally conserved at specific positions in the deduced amino acid sequences of VP2 of isolates from the United States (Serotype A1) and the 2 Jasper strains (Table 4). Sequences from all other isolates contained different amino acid residues at these positions. Similarly, unique signature amino acids were identified within VP2 for other groups or pairs of isolates (Table 5).

Classification on the basis of deduced amino acid similarities of VP2 demonstrated that the 28 aquatic birnavirus isolates clustered into 6 genogroups (Fig. 3). Genogroup 1 consisted of all isolates from the United States (Serotype A 1 ) and the 2 J asper strains. Genogroup 2 contained all of the isolates belonging to Serotype A3, including viruses from both Europe and Asia.

Two Canadian isolates representing Serotype A6 (C1 and ASV) and the type strain (Te) of European Serotype A 5 formed Genogroup 3. The type strains of the 2 Canadian Serotypes A 7 (C2) and A8 (C3) comprised Genogroup 4. All members of Serotype A2, including 5 European isolates and 1 Asian isolate, formed Genogroup 5. The He strain, the only known representative of Serotype A4, represented Genogroup 6. In general, these genogroups, based on deduced amino acid sequences of CDNA of the VP2 coding region of genome segment $A$, corresponded with geographic origin of the virus and previous classifications based on antigenic relationships. Genogroups 3,5 , and 6 corresponded exactly to 3 (A3, A2, A4, respectively) of the 9 serotypes. The other 3 genogroups (Genogroups 1, 2, and 4) each included members of 2 aquatic birnavirus serotypes ( $A 1$ and $A 9, A 7$ and $A 8$, $A 5$ and $A 6$, respectively). The phylogenetic tree also clearly shows that the viruses representing the 3 major serotypes found in Canada (A6, A 7, and A8) are more closely related to the European and Asian isolates (Serotypes A2, A3, A4, and A5) than to isolates representing the prevalent serotype (A1) in the United States and the J asper strains.

This correlation of genogroups based on the deduced amino acid sequences of the large ORF and the VP2 coding region with serological classification differs from a previous report by Heppell et al. (1993) which failed to demonstrate a clear correlation between genogroups based on genomic sequence similarities and serotypes of aquatic birnaviruses. However, their investigation focused on relatively short genomic sequences within the C-terminus-pVP2/NS junction coding region. NS protein is a non-structural protease. Our study concentrated on the entire large ORF or the entire VP2 coding region of genome segment A. Virion protein VP2 is the major outer capsid protein and the site of all neutralization epitopes. Examination in this study of the much larger genomic fragment encoding the entire VP2 protein from a relatively large number of isolates provides a more complete analysis of the genomic relationships of these viruses. Considering that VP2 is the outer capsid protein, it is not surprising that genogroups based on the deduced amino acid sequence of the entire VP2 protein generally correlates with serological classification and geographical origin. These results also are consistent with our previous study demonstrating a correlation between genogroups constructed on the basis of restriction fragment length polymorphisms (RFLP) of the VP2 coding region and serological classification based on reaction patterns with a panel of monoclonal antibodies (Lee et al. 1996).

The use of a relative large number of isolates representing a single serotype (A1) of aquatic birnaviruses in this study also indicates that classification of these viruses based on genomic sequences of the VP2 coding region is informative and correlates with serological classification of specific strains within a given serotype. Several genogroups identified in this study are comprised of 2 or more apparent genotypes. This is particularly evident in Genogroup 1, in which 4 genotypes can be identified that correspond to previously identified specific serological strains. Previous investigations using monoclonal antibodies have shown that at least 4 distinct strains of aquatic birnaviruses can be identified within Serotype A 1: WB strain, VR299 strain, Buhl strain, and Reno strain (Caswell-Reno et al. 1986, 1989, P. Reno, Oregon State University, pers. comm.). In this study, 5 viruses (Buhl, 91-114, 91-137, 64-93, and 90-11) that previously were shown to belong to a single serological strain (Buhl strain) within the A1 serotype were clustered in Genotype 1 . Three, or possibly 4, other genotypes also were identified within Genogroup 1. Genotype 2 included strain VR299 and the $\mathrm{aD}$ strain. This grouping also agrees with previous serological studies. VR299 represents a second distinct strain within Serotype A aquatic birnaviruses based on monoclonal antibody reaction patterns. Furthermore, Berthiaume et al. (1992) showed that VR299 and the $\mathrm{J} a \mathrm{D}$ strain are very similar antigenically based on ELISA with both polyclonal and monoclonal antibodies and they exhibited $100 \%$ homology in nucleotide sequences of a $359 \mathrm{bp}$ fragment of genome segment $A$. The Reno isolate, another serologically distinct strain, constituted Genotype 3. Genotype 4 was formed by WB and DM, both of which represent the same strain identified by monoclonal antibody reaction patterns. The J AATCC strain, which currently constitutes a sep- 
arate serotype, clearly was clustered in Genogroup 1 with the isolates from the United States and was more closely related to the WB strain. However, in conjunction with the previous serological data, the branching structure of the phylogenetic tree in this study suggests that the J asper-ATCC strain may represent a fifth genotype within Genogroup 1.

In summary, the results of this investigation of the genomic relationships of a relatively large number of aquatic birnaviruses from a variety of geographical areas worldwide demonstrate that these viruses represent at least 6 major genogroups. Furthermore, in contrast to previous studies of smaller genomic fragments from relatively few virus isolates, these genogroups generally correlate with geographical origin and previous serological classifications of these viruses based on reaction with polyclonal and monoclonal antibodies. This information and the availability of this sequence database of genome segment A will be useful in future studies of aquatic birnaviruses (e.g., epidemiological investigations) as well as in fish disease diagnostic programs. For example, currently we are typing new aquatic birnavirus isolates based on automated DNA sequencing of 300 to $500 \mathrm{bp}$ RT-PCR amplification products within the hypervariable region of the VP2 coding region and the comparison of these sequences with the sequence data developed in this investigation. This is relatively rapid ( 1 to $2 \mathrm{~d}$ ) and cost effective compared to isolation in cell culture and the use of a panel of monoclonal antibodies for identification of serotypes.

Acknowledgements. This work was supported by grants from the NOAA Sea Grant (R/FMD-217, R/FMD-235, R/FMD 257 and R/FMD 269), the NSF EPSCoR Program (EHR 91-08766), and the Maine Agricultural and Forest Experiment Station. Maine Agricultural and Forest Experiment Station Publication No. 2497.

\section{LITERATURE CITED}

Berthiaume L, Tarrab E, Heppell J , Arella M, Dobos P, Duncan R, Lecomte J (1992) Antigenic and genomic differences of two J asper strains of infectious pancreatic necrosis virus. Intervirology 34:197-201

Blake S, Schill LWB, McAllister PE, Lee MK, Singer JT, Nicholson BL (1995) Detection and identification of aquatic birnaviruses by PCR assay. J Clin Microbiol 33: 835-839

Caswell-Reno P, Reno PW, Nicholson BL (1986) Monoclonal antibodies to infectious pancreatic necrosis viruses: analysis of viral epitopes and comparison of different isolates. J Gen Virol 67:2193-2205

Caswell-Reno P, Lipipun V, Reno PW, Nicholson BL (1989) Use of a group reactive and other monoclonal antibodies in an enzyme immunodot assay for identification and presumptive serotyping of aquatic birnaviruses. J Clin Microbiol 27:1924-1929
Cohen J, Poinsard A, Scherrer R (1973) Physical, chemical and morphological features of infectious pancreatic necrosis virus. J Gen Virol 21:485-498

Dobos P, Roberts TE (1983) The molecular biology of infectious pancreatic necrosis virus: a review. Can J Microbiol 29:377-384

Dobos P, Hill BJ , Hallett R, Kells DTC, Becht H, Teninges D (1979) Biophysical and biochemical characterization of five animal viruses with bisegmented double-stranded RNA genomes. J Virol 32:593-605

Duncan R, Dobos P (1986) The nucleotide sequence of infectious pancreatic necrosis virus (IPNV) dsRNA A segment reveals one large ORF encoding a precursor protein. Nucleic Acids Res 14:5934-5935

Duncan R, Nagy E, Krell PJ, Dobos P (1987) Synthesis of the infectious pancreatic necrosis virus polyprotein, detection of a virus-encoded protease, and fine structure mapping of genome segment A coding regions. J Virol 61:3655-3664

Egusa S (1970) Branchionephritis prevalence among eel populations in farm-ponds in the winter of 1969-1970. Fish Pathol 5:51-56 (in J apanese)

Havarstein LS, Kalland KH, Christie KE, Endresen C (1990) Sequence of the large double-stranded RNA segment of the N1 strain of infectious pancreatic necrosis virus: a comparison with other Birnaviridae. J Gen Virol 71: 299-308

Heppell J, Berthiaume L, Corbin F, Tarrab E, Lecomte J, Arella M (1993) Comparison of amino acid sequences deduced from a cDNA fragment obtained from infectious pancreatic necrosis virus (IPNV) strains of different serotypes. Virology 195:840-844

Heppell J, Tarrab E, Berthiaume L, Lecomte J, Arella M (1995) Characterization of the small open reading frame on genome segment $A$ of infectious pancreatic necrosis virus. J Gen Virol 76:2091-2096

Hill BJ, Way K (1995) Serological classification of infectious pancreatic necrosis (IPN) virus and other aquatic birnaviruses. In: Hetrick F, Faisal M (eds) Annual review of fish diseases. Pergamon Press, New York, p 55-78

Lannan CN, Winton J R, Fryer J L (1984) Fish cell lines: establishment and characterization of nine cell lines from salmonids. In Vitro 20:107-144

Lee MK, Blake S, Singer J, Nicholson B (1996) Genomic variation of aquatic birnaviruses based on restriction fragment length polymorphisms (RFLP). Appl Environ Microbiol 62: 2513-2520

Lipipun V, Caswell-Reno P, Reno PW, Hsu YL, Wu J L, Nicholson BL (1992) Antigenic variation of aquatic birnavirus isolates. In: Shariff M, Subasinghe R, Arthur J R (eds) Proceedings of first symposium on diseases in Asian aquaculture. Asian Fisheries Society, Manilla, $p$ 237-245

Lo CF, Hong YW, Huang SY, Wang CH (1988) The characteristics of the virus isolated from the gill of clam, Meretrix lusoria. Fish Pathol 23:147-154

Macdonald RD, Yamamoto T (1977) The structure of infectious pancreatic necrosis virus RNA. J Gen Virol 34: 235-247

Magyar G, Dobos P (1994) Evidence for the detection of the infectious pancreatic necrosis virus polyprotein and the $17-\mathrm{kDa}$ polypeptide in infected cells and of the NS protease in purified virus. Virology 204:580-589

Manning DS, Leong J C (1990) Expression in Escherichia coli of the large genomic segment of infectious pancreatic necrosis virus. Virology 179:16-25

Manning DS, Mason CL, Leong J C (1990) Cell-free translational analysis of the processing of infectious pancreatic necrosis virus polyprotein. Virology 179:9-15 
Nagy E, Duncan R, Krell P, Dobos P (1987) Mapping of the large RNA genome segment of infectious pancreatic necrosis virus by hybrid arrested translation. Virology 158: 211-217

Nicholson BL (1993) Use of monoclonal antibodies in fish disease research. In: Hetrick F, Faisal M (eds) Annual review

Editorial responsibility: J o-Ann Leong,

Corvallis, Oregon, USA of fish diseases. Pergamon Press, N ew York, p 241-257

Wolf K (1988) Fish viruses and fish viral diseases. Cornell University Press, Ithaca, NY

Yao K, Vakharia VN (1998) Generation of infectious pancreatic necrosis virus from cloned cDNA. J Virol 72: 8913-8920

Submitted: September 20, 2000; Accepted: M arch 12, 2001 Proofs received from author(s): J une 6, 2001 